\title{
Field Scale Modeling to Estimate Phosphorus and Sediment Load Reductions Using a Newly Developed Graphical User Interface for Soil and Water Assessment Tool
}

\author{
${ }^{1}$ Aaron R. Mittelstet, ${ }^{2}$ Erin R. Daly, \\ ${ }^{3}$ Daniel E. Storm, ${ }^{4}$ Michael J. White and ${ }^{5}$ Greg A. Kloxin \\ ${ }^{1}$ Department of Biosystems and Agricultural Engineering, \\ Oklahoma State University, 114 Agricultural Hall, Stillwater, OK, 74078-6016, USA \\ ${ }^{2}$ Department of Biosystems and Agricultural Engineering, \\ Oklahoma State University, 209 Agricultural Hall, Stillwater, OK, 74078-6016, USA \\ ${ }^{3}$ Department of Biosystems and Agricultural Engineering, \\ Oklahoma State University, 111 Agricultural Hall, Stillwater, OK, 74078-6016, USA \\ ${ }^{4}$ USDA-ARS Grassland, Soil and Water Research Laboratory \\ 808 East Blackland Road Temple, TX, 76502-6712, USA \\ ${ }^{5}$ Water Quality Division, Oklahoma Conservation Commission, \\ 4545 N Lincoln Blvd, Lincoln Plaza Office, Suite 11A, Oklahoma City, OK 73105, USA
}

Received 2012-07-26, Revised 2012-12-28; Accepted 2012-12-28

\begin{abstract}
Streams throughout the North Canadian River watershed in northwest Oklahoma, USA have elevated levels of nutrients and sediment. Soil and Water Assessment Tool (SWAT) was used to identify areas that likely contributed disproportionate amounts of Phosphorus (P) and sediment to Lake Overholser, the receiving reservoir at the watershed outlet. These sites were then targeted by the Oklahoma Conservation Commission (OCC) to implement conservation practices, such as conservation tillage and pasture planting as part of a US Environmental Protection Agency Section 319(h) project. Conservation practices were implemented on 238 fields. The objective of this project was to evaluate conservation practice effectiveness on these fields using the Texas Best Management Evaluation Tool (TBET), a simplified Graphic User Interface (GUI) for SWAT developed for field-scale application. TBET was applied on each field to predict the effects of conservation practice implementation on $\mathrm{P}$ and sediment loads. These predictions were used to evaluate the implementation cost (per $\mathrm{kg}$ of pollutant) associated with these reductions. Overall the implemented practices were predicted to reduce $\mathrm{P}$ loads to Lake Overholser by nine percent. The 'riparian exclusion' and 'riparian exclusion with buffer' practices provided the greatest reduction in P load while 'conservation tillage' and 'converting wheat to bermuda grass' produced the largest reduction in sediment load. The most cost efficient practices were 'converting wheat to bermuda grass' or 'native range' and 'riparian exclusion'. This project demonstrates the importance of conservation practice selection and evaluation prior to implementation in order to optimize cost share funds. In addition, this information may lead to the implementation of more cost effective practices and an improvement in the overall effectiveness of water quality programs.
\end{abstract}

Keywords: SWAT, Phosphorus Management, Hydrologic Modeling, Conservation Practices, CostEffectiveness

Corresponding Author: Aaron R. Mittelstet, Department of Biosystems and Agricultural Engineering, Oklahoma State University, 114 Agricultural Hall, Stillwater, OK, USA 74078-6016 


\section{INTRODUCTION}

In agricultural watersheds, non-point sources are often the dominate contributor to water quality impairment (Allan, 1995; Rao et al., 2009). Phosphorus (P) and sediment are two of the most common contributors to aquatic impairment with agricultural sources responsible for $46 \%$ of the sediment and $47 \%$ of the $\mathrm{P}$ released into U.S. waters (Allan, 1995; Rao et al., 2009). Phosphorus is a necessary nutrient for agricultural crops, yet over application of fertilizer may lead to elevated $\mathrm{P}$ levels in streams, reservoirs and lakes. Several conservation practices are effective in reducing sediment and $\mathrm{P}$ loss from agricultural fields, including riparian buffers, conservation tillage, crop rotation and vegetative filter strips. The Environmental Quality Incentives Program (EQIP), which is administered by the US Department of Agricultural (USDA) Natural Resources Conservation Service (NRCS), provides assistance for landowners seeking to establish conservation practices and received \$1.02 billion nationally in 2006 (Canada and Zinn, 2005). The Clean Water Act, Section 319, program administered by the US Environmental Protection Agency (USEPA) distributed \$201 million in federal funds, which required a $40 \%$ state match, to states for use in nonpoint source pollution reduction projects (USEPA, 2007). Both the USEPA and the USDA have expressed significant interest in evaluating the effectiveness of these programs.

Published data on $\mathrm{P}$ and sediment reduction for various conservation practices are available, but these data provide only a general estimate of practice efficiency as site characteristics inherently vary. Use of a watershed or field-scale hydrologic model provides an alternative to these generalized efficiencies and may produce more accurate estimation of site specific $\mathrm{P}$ and sediment reductions from conservation practice implementation. Soil and Water Assessment Tool (SWAT) (Arnold et al., 1998) is a watershed scale model widely used to evaluate conservation programs. SWAT was utilized by Tuppad et al. (2010) and Vache et al. (2002) to model the reduction of sediment and nutrients due to conservation practice implementation. Simulated scenarios by Tuppad et al. (2010) demonstrated decreases from 3 to $37 \%$ for sediment load and up to a $30 \%$ decrease in total $\mathrm{P}$ load for individual conservation practices for the Bosque River watershed in northern Texas, USA. Vache et al. (2002) examined three future land use scenarios in central Iowa, USA where two of the scenarios showed significant reductions in sediment and nutrient loads. By using a combination of conservation practices, e.g., conservation tillage, strip intercropping, rotational grazing, predicted sediment loads were reduced by 37 to $67 \%$ and nutrients by 54 to $75 \%$. Many other researchers have also used SWAT to evaluate conservation practices in a variety of systems (Chu et al., 2005; Bracmort et al., 2006; White et al., 2010).

Though several studies have evaluated the effect of conservation practice implementation on $\mathrm{P}$ and sediment losses from agricultural fields, few have considered the cost per unit load reduction. It is important to make this information available to policy makers to aid them in determining the largest $\mathrm{P}$ and sediment reduction for the least cost. Secchi et al. (2007) found that by implementing conservation practices in 13 Iowa watersheds, SWAT predicted sediment loads could be reduced from 6 to $65 \%$ and the $\mathrm{P}$ loads from 28 to $59 \%$ at a cost of \$2.4-4.3 billion over ten years. Chang et al. (2009) evaluated the number and location of conservation practices versus pollutant reduction. They demonstrated that although there continued to be a reduction in pollutant load per added conservation practice, there was an optimal quantity of conservation practices where the largest pollutant reduction per cost was achieved. Gitau et al. (2004) utilized SWAT to determine the optimal selection and placement of conservation practices to identify costeffective solutions for nonpoint source reduction. Schwartz (2010) used watershed-scale optimization to inform decision makers of the most cost efficient nutrient reduction strategies. While models like SWAT are valuable tools for highly trained specialists, their complexity prohibits their use by most conservation and nutrient management planners. The Texas Best management practice Evaluation Tool (TBET) was designed to simplify the operation of SWAT in order to put the predictive power of a proven water quality model into the hands of people who make daily decisions that affect water quality.

This project involved three stages with the bulk of the study focusing on the final stage of the project, the modeling of the fields that were identified as targeted areas. The first stage of the project was to identify the areas (targeted areas) within the watershed that contributed a large percent of the $\mathrm{P}$ and sediment to the stream system. The second stage was the implementation of the best management practices by the Oklahoma Conservation Commission. The third stage and the focus of this study was to estimate the reduction in total $\mathrm{P}$ and sediment loads from 238 fields in the North Canadian Watershed in northwestern Oklahoma resulting from the implementation of conservation practices using TBET. Costs for conservation practice implementation for both 
the federal government and the rancher and farmer per $\mathrm{Mg}$ of sediment and $\mathrm{kg}$ of total $\mathrm{P}$ reduction were also calculated and their efficiencies evaluated.

\subsection{Background \\ 1.1.1. Study Area}

The Canton-Overholser corridor of the North Canadian watershed (Fig. 1) which includes parts of Blaine, Canadian and Dewey Counties, located in northwest Oklahoma, USA, occupies a drainage area of approximately $1,970 \mathrm{~km}^{2}$. Streams throughout this wheat and cattle producing area are impaired due to excess nutrients, suspended solids and siltation. Designated uses for the waterbodies include primary body contact recreation, fish and wildlife propagation, public and private water supply, aesthetics, industrial and municipal process and cooling water and agriculture (OCC, 2008). The soils are predominantly made up of highly erodible sandy, silty or clay loams.

\subsection{Identification of Targeted Areas (Stage 1)}

The first stage of the project was to use SWAT to identify the non-urban areas within the North Canadian watershed that contributed disproportionate nutrient loads (Fig. 1a). For more information on the model setup, calibration, etc. of the watershed see Storm et al. (2007). The results of the SWAT model indicated that cropland (small grain and row crops), bare soil and urban development were found to be the primary sources of nutrient and sediment loads. The identified targeted (non-urban) areas made up a total of $54 \mathrm{~km}^{2}$ or approximately $3 \%$ of the total watershed area.

Several scenarios of conservation practice implementation were simulated to determine potential total P load reductions at the watershed outlet. If all fields with small grains and row crops implemented conservation tillage with farming on the contour, total $\mathrm{P}$ loads were predicted to be reduced by $22 \%$. By converting all small grains and row crops to pasture or all grazing pastures to hay, $\mathrm{P}$ loads were predicted to be reduced by 15 and $12 \%$, respectively. The greatest single $\mathrm{P}$ load reduction $(22 \%)$ resulted from adding a $10 \mathrm{~m}$ buffer strip to all agricultural lands bordering the Northern Canadian River and its tributaries.

\subsection{Conservation Practice Implementation (Stage 2)}

The Oklahoma Conservation Commission (OCC) applied limited funding from the US Environmental Protection Agency 319(h) Program to cost share the implementation of conservation practices at 238 field sites within the watershed project area to reduce total $\mathrm{P}$ andsediment loads (Fig. 1b). Although the OCC prioritized the implementation of best management practices based on Storm et al. (2007) implementation efforts were ultimately constrained by landowner participation. The 238 field sites where the best management practices were implemented occupied a total of $65 \mathrm{~km}^{2}(3.2 \%$ of the watershed area), with field sizes ranging from 0.01 to $1.2 \mathrm{~km}^{2}$. The targeted areas identified by Storm et al. (2007) and field sites with implemented conservation practices mutually occurred on 44 of the 238 field sites with an area of $14 \mathrm{~km}^{2}$.

Five types of conservation practices were implemented within the watershed individually or together with annual costs provided in Table 1. The fraction of the total cost subsidized by the cost share program differed by practice (USDA-NRCS, 2011). For some practices, such as conservation tillage, $100 \%$ of the cost was paid by the federal government. For other costs, such as the installation of fence and the establishment of bermuda grass, the cost was shared between the government $(80 \%)$ and the farmer or rancher (20\%). Some practices required single implementation (conservation tillage), while others required multiple installations such as animal exclusion (fence, watering facility, pipeline and pump). The practical life of the conservation practices were also taken into account. For example, based on the USDA NRCS Field Office Technical Guide (FOTG), native rangeland implementation had a practical life of 10 years compared to 20 years for a watering facility (USDA-NRCS, 2011).

\section{MATERIALS AND METHODS}

\subsection{Texas Best Management Evaluation Tool}

The Texas Best management practice Evaluation Tool (TBET) is based on a specially modified version of Soil and Water Assessment Tool (SWAT) 2009 (Arnold et al., 1998) a product of more than 30 years of model development by the USDA, Agricultural Research Service. The field-scale model is a vastly simplified Graphical User Interface (GUI) which includes numerous updates and local climate, soils, topography and management databases supporting it's usage throughout south central US. Required data for TBET simulations include crop system and management practices, soil type, field area, distance to stream and soil test phosphorus. 


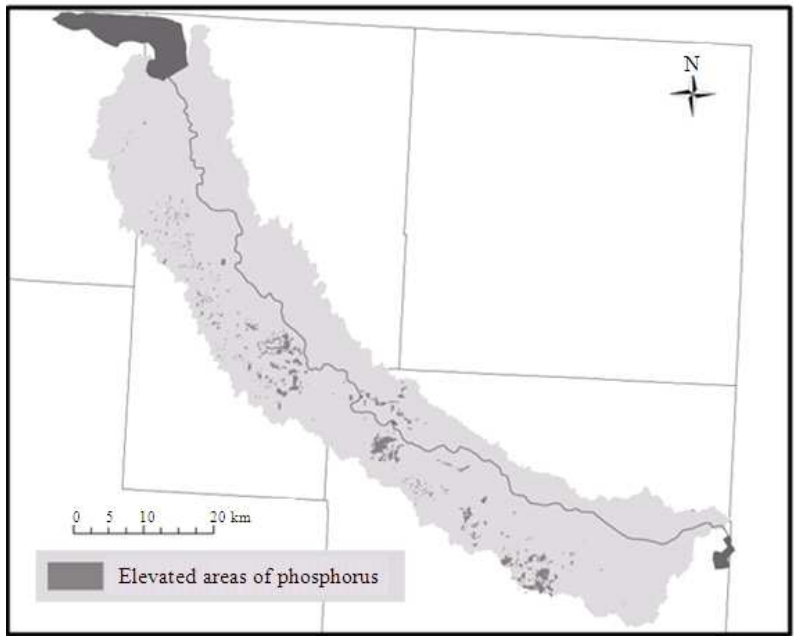

(a)

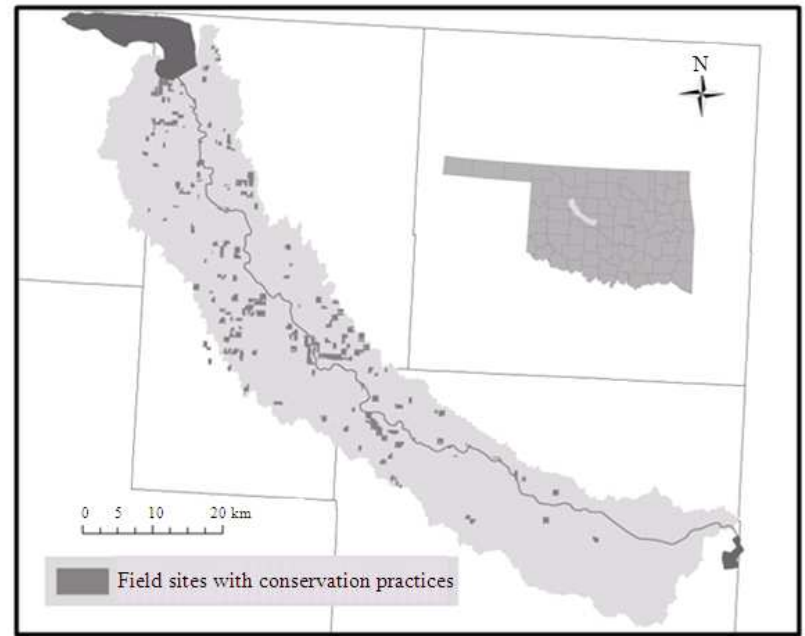

(b)

Fig. 1. The North Canadian River Watershed Project area in northwest Oklahoma, USA with Canton Lake in the north draining to Lake Overholser in the south connected by the North Canadian River. The location of the elevated areas of phosphorus loss identified by SWAT (a) Elevated areas of phosphorus and the locations of the 238 field sites where the conservation practices were implemented (b)Field sites with conservation practices

Table 1. Conservation practices implemented in the North Canadian River Watershed Project, their costs to the federal government and the ranchers and farmers and their practical life expectancy (USNRCS 2011)

\begin{tabular}{|c|c|c|c|c|c|}
\hline $\begin{array}{l}\text { Conservation } \\
\text { Practice }\end{array}$ & $\begin{array}{l}\text { No. } \\
\text { of fields }\end{array}$ & $\begin{array}{l}\text { Total } \\
\text { area (ha) }\end{array}$ & $\begin{array}{l}\text { Cost to } \\
\text { federal government }\end{array}$ & $\begin{array}{l}\text { Cost to } \\
\text { farmer or rancher }\end{array}$ & $\begin{array}{l}\text { Practical } \\
\text { Life (yrs) }\end{array}$ \\
\hline Conservation tillage & 205 & 6040 & $\$ 52.22 /$ ha $(100 \%)$ & $\$ 0.00(0 \%)$ & 1 \\
\hline Wheat to bermuda & 23 & 305 & $\$ 207.44 /$ ha $(80 \%)$ & $\$ 51.86 / \mathrm{ha}(20 \%)$ & 10 \\
\hline Wheat to native range & 2 & 37 & $\$ 201.85 /$ ha $(80 \%)$ & $\$ 50.46 /$ ha $(20 \%)$ & 10 \\
\hline \multirow[t]{4}{*}{ Riparian exclusion } & 2 & 13 & $\$ 4.78$ / linear $m$ fence $(90 \%)$ & $\$ 0.53$ /linear $\mathrm{m}$ fence $(10 \%)$ & 20 \\
\hline & & & $\$ 5.08 /$ linear $\mathrm{m}$ pipe $(90 \%)$ & $\$ 0.51 /$ linear $\mathrm{m}$ pipe $(10 \%)$ & 20 \\
\hline & & & Watering facility-\$625.93 (90\%) & Watering facility-\$69.55 (10\%) & 10 \\
\hline & & & Solar water pump- $\$ 5,636.25(90 \%)$ & Solar water pump-\$626.25 (10\%) & 15 \\
\hline \multirow{5}{*}{$\begin{array}{l}\text { Riparian exclusion } \\
\text { with conservation } \\
\text { tillage }\end{array}$} & 2 & 45 & $\$ 4.78$ / linear $\mathrm{m}$ fence $(90 \%)$ & $\$ 0.53 /$ linear $\mathrm{m}$ fence $(10 \%)$ & 20 \\
\hline & & & $\$ 5.08 /$ linear $\mathrm{m}$ pipe $(90 \%)$ & $\$ 0.51 /$ linear $m$ pipe $(10 \%)$ & 20 \\
\hline & & & Watering facility-\$625.93 $(90 \%)$ & Watering facility-\$69.55 (10\%) & 10 \\
\hline & & & Solar water pump- $\$ 5,636.25(90 \%)$ & Solar water pump-\$626.25 (10\%) & 15 \\
\hline & & & $\$ 48.70 \mathrm{ha}^{-1}(100 \%)$ & $\$ 0.00$ & 1 \\
\hline \multirow{5}{*}{$\begin{array}{l}\text { Riparian exclusion } \\
\text { with buffer }\end{array}$} & 4 & 33 & $\$ 4.78$ linear $\mathrm{m}$ fence $(90 \%)$ & $\$ 0.53 /$ linear $\mathrm{m}$ fence $(10 \%)$ & 20 \\
\hline & & & $\$ 5.08 /$ linear m pipe $(90 \%)$ & $\$ 0.51 /$ linear $\mathrm{m}$ pipe $(10 \%)$ & 20 \\
\hline & & & Watering facility-\$625.93 (90\%) & Watering facility-\$69.55 (10\%) & 10 \\
\hline & & & Solar water pump- $\$ 5,636.25(90 \%)$ & Solar water pump-\$626.25 (10\%) & 15 \\
\hline & & & $\$ 223.20 \mathrm{ha}^{-1}$ (Excluded) $(100 \%)$ & $\$ 0.00(0 \%)$ & 15 \\
\hline
\end{tabular}

TBET was developed for use in state- and federally- sponsored water quality improvement programs to assist in the selection of optimal conservation practices and to estimate and evaluate the resulting pollutant reductions. The model interface acts as an input and output interpreter for the SWAT model and insulates the conservation planner from the model complexities of SWAT. TBET supports common NRCS conservation practices and predicts sediment, phosphorus and nitrogen losses from individual fields that comprise a farm and/or ranch operation. By using the process-based SWAT model, this tool more accurately simulates a wide variety of management options and field characteristics. A rigorous, data intensive calibration and validation process was employed in TBET development (White et al., 2012). First, hydrology outputs were calibrated with basin scale streamflow data from 20 USGS sites. 
Table 2. Crop management data for TBET simulations with crop system, fertilization and grazing management data and field Mehlich III Soil Test Phosphorus levels

\begin{tabular}{llll}
\hline $\begin{array}{l}\text { Crop } \\
\text { system }\end{array}$ & $\begin{array}{l}\text { Fertilizer rates and } \\
\text { time of application }\end{array}$ & $\begin{array}{l}\text { Grazing management } \\
\text { (animal unit/ha) }\end{array}$ & $\begin{array}{l}\text { Soil test } \\
\text { phosphorus (ppm) }\end{array}$ \\
\hline Winter wheat & $34 \mathrm{~kg} \mathrm{~N}, 2.7 \mathrm{~kg}$ P (Pre-plant) & 0.82 & $39-41$ \\
Bermuda grass & $136 \mathrm{~kg} \mathrm{~N}, 34 \mathrm{~kg} \mathrm{P}$ (Spring) & 1.85 & 40 \\
Native range & None & 0.62 & $26-30$ \\
\hline
\end{tabular}

Then, runoff, sediment and total $\mathrm{N}$ and $\mathrm{P}$ outputs were calibrated and validated with measured field scale data $(260+$ site years). The sites varied based on cropping system, location, nutrient application rates and timing, field sizes, soil types and Soil Test Phosphorus (STP) levels. A total of 331, 332 and 341 site years of field scale data for runoff, sediment and total $\mathrm{P}$ were obtained. The $\mathrm{r}^{2}$ were $0.64,0.28$ and 0.76 , respectively.

\subsection{Phosphorus and Sediment Load Modeling (Stage 3)}

Each of the 238 field sites was modeled pre- and post-conservation practice implementation. The OCC provided the locations and areas of the 238 field sites and the type or types of conservation practices implemented. Other input needs were soil type, slope, landcover and management practices (Table 2).

In TBET up to three soil types and their percentages can be selected for each field site. SSURGO data (USDA-NRCS, 2007) were chosen due to its high resolution. Slopes from $0.01-12.7 \%$ with an average of $2.2 \%$ were calculated in ESRI ArcGIS using $10-\mathrm{m}$ National Elevation Dataset (NED) (USGS, 1999). The National Agricultural Statistics Service (30-m resolution) (USDA-NRCS, 2009) dataset was used to obtain the current landcover for each field site, which were then verified by OCC personnel knowledgeable in the area. The majority of the field sites were wheat fields, but also included pasture and rangeland. Crop management data were obtained from the OCC, Oklahoma State Cooperative Extension papers (PSS-2263 and NREM2869) and from Hossain et al. (2004) (Table 2). Soil test phosphorus levels were based on a previous survey from Storm et al. (2007).

\subsection{Best Management Practices}

\subsubsection{Conservation Tillage (NRCS Code 344)}

This practice involves leaving plant residue on the soil surface year round while limiting soil activities to only those that are necessary such as planting, harvesting and fertilization (USDA-NRCS, 2011). This reduces both the sediment and nutrient losses from the field site.
For this project pre-conservation practice conditions were modeled with conventional tillage and postconservation practice conditions were modeled with conservation tillage with $70 \%$ crop residue remaining on the surface.

\subsection{Converting Wheat to Bermuda or Native Range (NRCS Codes 512 and 550)}

The second and third practices involve planting bermuda or a native grass to improve livestock nutrition (USDA-NRCS, 2011). By maintaining cover year round, the soil erosion and $\mathrm{P}$ and $\mathrm{N}$ losses decrease. For this project all fields were modeled as both grazed and ungrazed and the average of the model results used for all statistics. This was because anywhere from $30-70 \%$ of the fields may be grazed in any one year due to changes in cattle prices, precipitation and other factors. Grazing was assumed to be continuous for a 90 day period at various densities (Table 2).

\subsection{Riparian Exclusion (NRCS Codes 382, 516 and 614)}

The fourth conservation practice implemented was riparian exclusion. This included the installation of fences (Code 382) to prevent animal entry and establish/reestablish riparian vegetation for filtering and stabilizing benefits. It also included the installation of a pipeline (Code 516) and watering facility (Code 614) to convey water from a source to the livestock. These field sites were only modeled as grazed since fields without cattle would not need exclusion. This conservation practice was implemented individually or coupled with conservation tillage or a buffer.

\subsection{Riparian Forest Buffer (NRCS Code 391)}

The fifth conservation practice involves the maintaining of trees along a water body to reduce excess sediment, $\mathrm{P}$ and $\mathrm{N}$ to receiving water bodies. This practice also creates shade, provides habitat, increases carbon storage and restores riparian plant communities. This practice was implemented with riparian exclusion. 


\section{RESULTS}

The average annual reduction from the 238 field sites due to the implementation of the conservation practices was $4,200 \mathrm{~kg}$ of P per year $\left(0.65 \mathrm{~kg} \mathrm{ha}^{-1}\right.$ year $\left.^{-1}\right)$ and 3,000 $\mathrm{Mg}$ of sediment per year $\left(0.47 \mathrm{Mg} \mathrm{ha}^{-1}\right.$ year $\left.^{-1}\right)$. This corresponded to a nine percent average annual reduction in P load to Lake Overholser based on loads estimated by Storm et al. (2007). The average percent reduction for each field site for the practice 'conservation tillage' was $38 \%$ for sediment and $34 \%$ for P. This was comparable to the predicted results by Santhi et al. (2006) of a $29-41 \%$ reduction in sediment and $12-25 \%$ for $\mathrm{P}$. The other practices were also comparable to Santhi et al. (2006) with a $76 \%$ reduction in $\mathrm{P}$ for 'riparian buffer', a $71-78 \% \mathrm{P}$ reduction and $98-99 \%$ sediment reduction for the practices 'wheat to bermuda' and 'wheat to native range'.

The majority of the total watershed reductions were from the 'conservation tillage' and 'wheat to bermuda' practices due to the large number of fields where these practices were implemented; however the largest reductions in $\mathrm{P}$ and sediment per unit area were achieved with the 'riparian exclusion with buffer' (i.e., cattle exclusion) and the 'wheat to bermuda' practices, respectively (Fig. 2). Although 'riparian exclusion' greatly reduced $\mathrm{P}$ loads to the stream, it did little for the predicted sediment load reductions (neglecting streambank erosion). On the other hand, 'conservation tillage' and 'converting wheat to bermuda' significantly reduced both $\mathrm{P}$ and sediment loads.
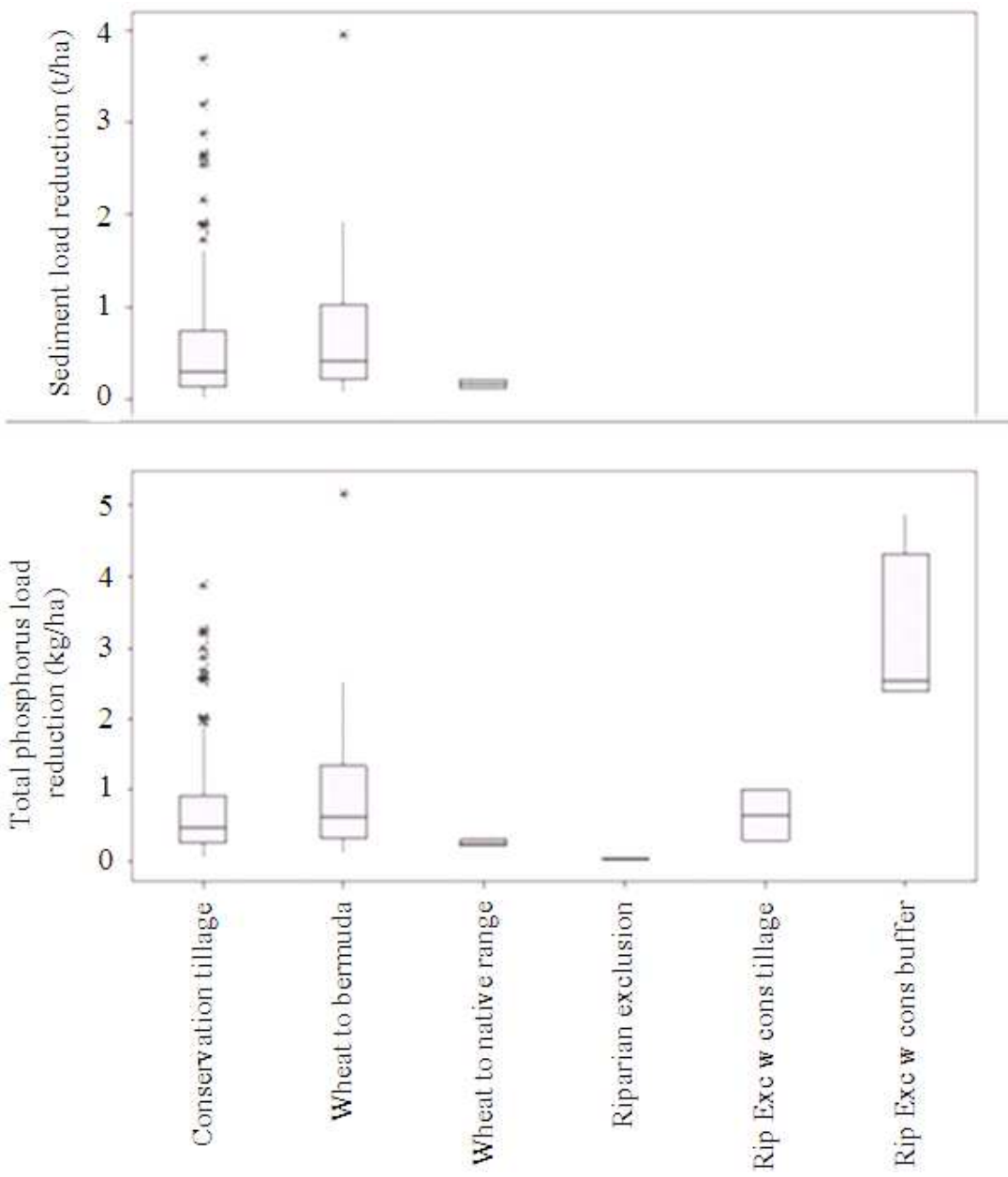

Fig. 2. Unit area $P$ and sediment load reduction per year summary for each conservation practice for the 238 fields sites based on TBET simulations $($ Rip $=$ Riparian; Exe $=$ Exclusion; Cons $=$ Conservation; $w=$ with; Exclusion $=$ cattle exclusion $)$ 


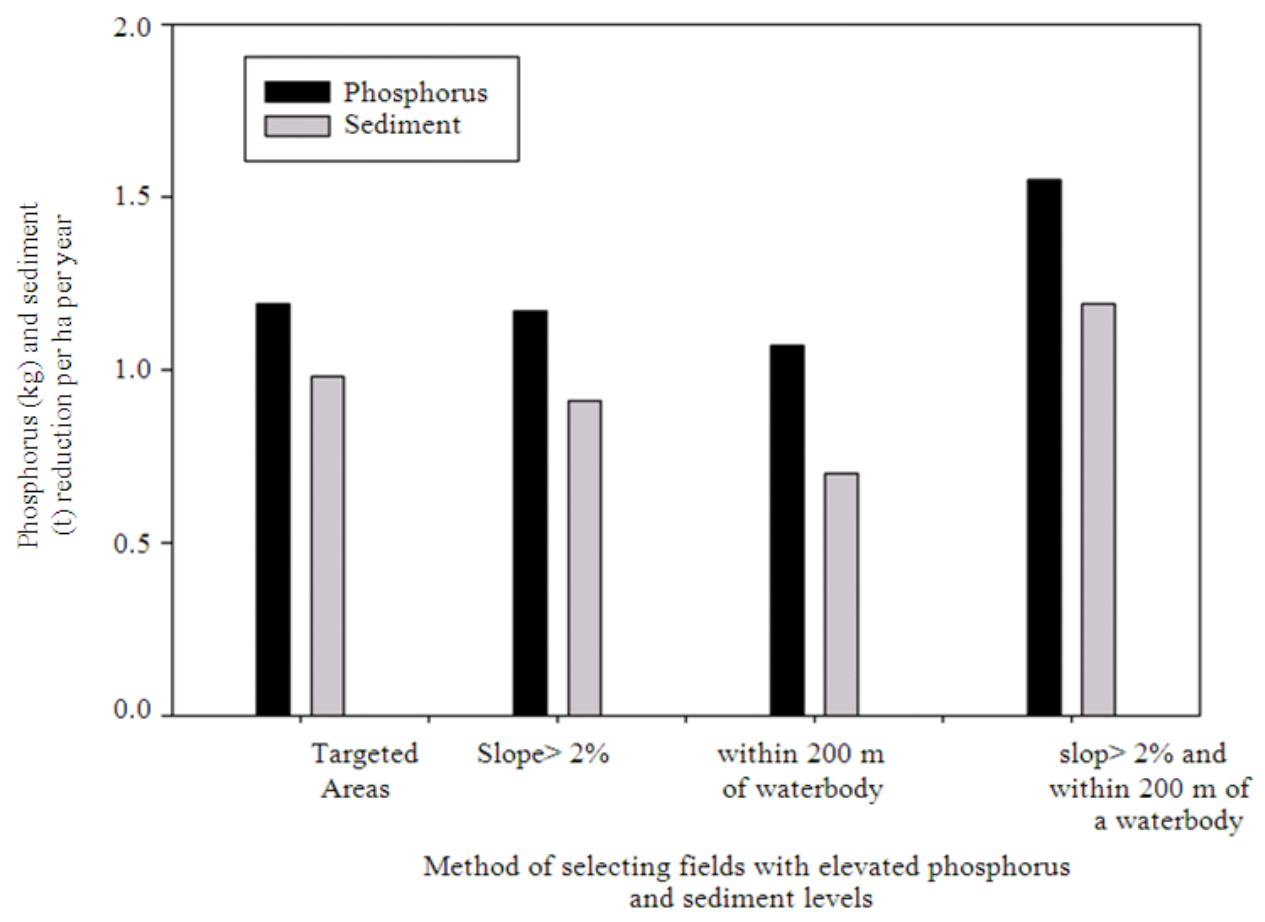

Fig. 3. Average annual unit area total phosphorus and sediment load reductions from targeted areas, field sites with slopes greater than $2 \%$ and fields within 200 m of a waterbody

Based on a Mann-Whitney ranked sum test, the median $\mathrm{P}$ reduction for the conservation practice 'converting wheat to bermuda' was not significantly greater than the median $\mathrm{P}$ reduction due to 'conservation tillage' at a $\mathrm{p}$-value of 0.05 (0.62 and $\left.0.47 \mathrm{~kg} \mathrm{ha}^{-1}\right)$; however it had a significantly greater reduction $(\mathrm{p}>0.044)$ in sediment (0.41 and $0.29 \mathrm{Mg} \mathrm{ha}^{-1}$ ). Statistical analysis was not performed on the other conservation practices due to their small sampling size.

The Mann-Whitney rank sum test was also utilized to analyze the effect of field slope and distance to a waterbody on $\mathrm{P}$ and sediment loads. Fields with a slope greater than $2 \%$ (112 fields) had a median $\mathrm{P}$ load reduction of $0.95 \mathrm{~kg} \mathrm{ha}^{-1}$ and the load reductions were significantly greater than fields with a slope less than $2 \%$ (126 fields) with a reduction of $0.29 \mathrm{~kg} \mathrm{ha}^{-1}$. The results were similar for sediment loads with a reduction of 0.76 $\mathrm{Mg} \mathrm{ha}^{-1}$ for the fields with a greater than a $2 \%$ slope and $0.19 \mathrm{Mg} \mathrm{ha}^{-1}$ for the fields with less than a $2 \%$ slope. There were 99 fields within a distance of $200 \mathrm{~m}$ of a waterbody (based on 1: 24,000 USGS blue line streams) that contributed median $\mathrm{P}$ and sediment load reductions of $0.76 \mathrm{~kg} \mathrm{ha}^{-1}$ and $0.41 \mathrm{Mg} \mathrm{ha}^{-1}$, respectively. These were significantly greater than the fields with distances greater than $200 \mathrm{~m}$ from a waterbody where the median $\mathrm{P}$ and sediment loads were reduced by $0.41 \mathrm{~kg} \mathrm{ha}^{-1}$ and $0.25 \mathrm{Mg} \mathrm{ha}^{-1}$, respectfully.

Each had a p-value less than 0.005 . Forty of the field sites where conservation practices were implemented were targeted areas by Storm et al. (2007). The median P reduction from these 44 field sites was $1.13 \mathrm{~kg} \mathrm{ha}^{-1}$ compared to $0.41 \mathrm{~kg} \mathrm{ha}^{-1}$ for the non-targeted field sites. The median sediment loads were also significantly greater with a $0.88 \mathrm{Mg} \mathrm{ha}^{-1}$ reduction for the targeted areas and $0.24 \mathrm{Mg} \mathrm{ha}^{-1}$ for the remaining sites. Fifty field sites had both a slope greater identified as than $2 \%$ and were within $200 \mathrm{~m}$ of a waterbody. Of the 50 sites, $42 \%$ were also targeted areas. These sites had median $\mathrm{P}$ and sediment reductions of $1.38 \mathrm{~kg} \mathrm{ha}^{-1}$ and $1.08 \mathrm{Mg} \mathrm{ha}^{-1}$, respectfully (Fig. 3).

\section{DISCUSSION}

When selecting conservation practice(s) to implement, their life expectancy and the total cost of $\mathrm{P}$ and sediment load reduction should be considered. For example, the cost per ha for 'conservation tillage' implementation was \$52.24 with a life expectancy of one year. 
Aaron R. Mittelstet et al. / American Journal of Environmental Science 8 (6) (2012) 605-614
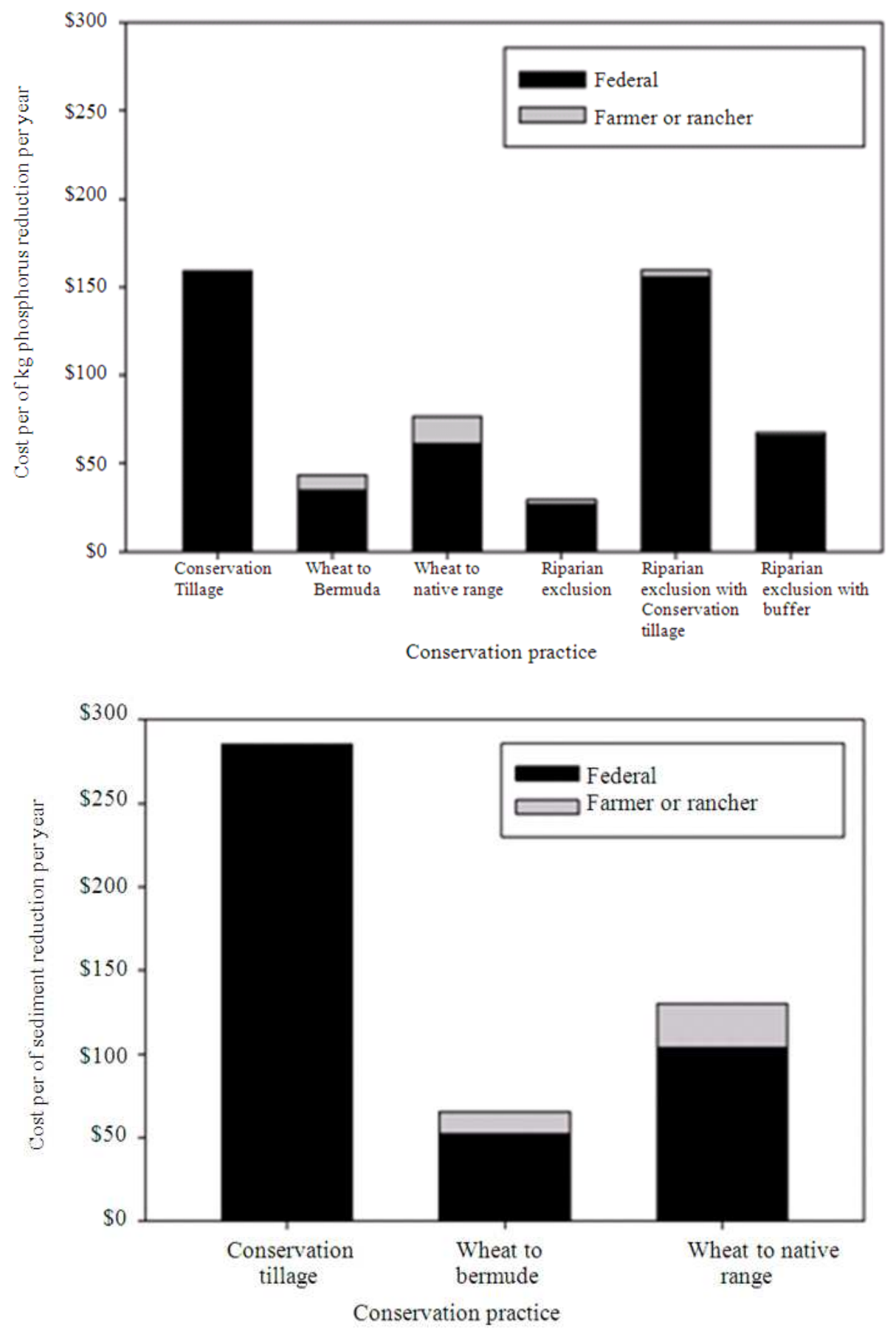

Fig. 4. Conservation practice implementation cost for both the federal government and the farmer or rancher for total phosphorus and sediment load reduction in 2011 USA dollars

For those practices with multiple years of life expectancy, the Net Present Value (NPV) was calculated using an interest rate of 5\% (USDA-NRCS, 2011) and the Equation 1: 


$$
P V(C)=\sum_{t=0}^{n} \frac{C_{t}}{(1+i)^{t}}
$$

where, $\mathrm{C}$ denotes the cost, $\mathrm{t}$ the time period and $\mathrm{i}$ the interest rate (Boardman et al., 2011). For example, for the conservation practice 'converting wheat to bermuda' with a life expectancy of 10 years, the cost to the federal government was $\$ 207.44 \mathrm{ha}^{-1}$ or $\$ 20.74 \mathrm{ha}^{-1}$ for the first year and $\$ 12.74 \mathrm{ha}^{-1}$ for the 10th year. The average cost over the ten year period was then utilized to calculate the cost per reduction per year. Based on this method, 'converting wheat to bermuda' cost $\$ 65.52$ per $\mathrm{Mg}$ of sediment reduced and $\$ 43.22$ per $\mathrm{kg}$ of $\mathrm{P}$. These were both significantly less than the load reductions for 'conservation tillage' with a sediment reduction of $\$ 285.19$ per $\mathrm{Mg}$ and $\$ 159.38$ per $\mathrm{kg}$ of $\mathrm{P}$. Statistics were not utilized with the remaining practices due to their small sample sizes. The most cost efficient practice for sediment reduction was 'converting wheat to bermuda'. For $\mathrm{P}$ reduction, 'converting wheat to bermuda' and 'riparian exclusion' were the most efficient.

Finally, when deciding which conservation practice (s) to promote to the farmers and ranchers, it is important to consider the costs to both the landowner and the federal government (Fig. 4). Typically farmers and ranchers are more willing to implement conservation practices that pay for themselves with increased crop yields or decreased inputs, are easy to install and maintain and do not alter their management requirements. However, each conservation practice considered in this project requires some change in management. Thus, the cost share rate must provide the incentive to implement the practice, or the practice must provide a reasonable cost savings or increased revenue. For example, to convert from conventional to conservation tillage, the additional capital investment requirement to purchase additional equipment and the added pesticide costs may be offset by reduced fertilizer and fuel costs and improved soil quality resulting in increased crop yields. Based on the results from this project, the most cost efficient reduction of $\mathrm{P}$ to both the farmer and the federal government was 'converting wheat to bermuda' and 'riparian exclusion' and for sediment reduction the most cost effective conservation practice was 'converting wheat to bermuda'. However, the potential reduction in economic returns from bermuda compared to wheat production should also be considered. In addition, the increased management requirements for riparian exclusion may also be a factor for some farmers and ranchers.

\section{CONCLUSION}

Agricultural fields contribute a large percentage of $\mathrm{P}$ and sediment to the nation's waterways each year. Implementing conservation practices can aid in reducing these pollutant loads and thereby have the potential to increase the water quality in the receiving streams, rivers, reservoirs and lakes. This study modeled $\mathrm{P}$ and sediment loads from 238 field sites before and after the implementation of conservation practices. The total load reduction, load reduction per ha and the efficiency of each conservation practice were analyzed using TBET. The average annual reduction from the 238 field sites due to the implementation of the conservation practices was $4,200 \mathrm{~kg}$ of $\mathrm{P}$ per year $\left(0.65 \mathrm{~kg} \mathrm{ha}^{-1}\right.$ year $\left.^{-1}\right)$ and $3,000 \mathrm{Mg}$ of sediment per year $\left(0.47 \mathrm{Mg} \mathrm{ha}^{-1} \mathrm{year}^{-1}\right)$. This corresponded to a nine percent annual reduction in P load to Lake Overholser based on loads estimated by Storm et al. (2007). Results from these model simulations demonstrated that the conservation practices 'riparian exclusion with buffer' and 'converting wheat to bermuda' had the largest $\mathrm{P}$ and sediment reductions, respectively. The most cost efficient practices were 'riparian exclusion' for $\mathrm{P}$ reduction and 'converting wheat to bermuda' for sediment reduction.

Based on these results, an agency can determine where and what conservation practice they want to implement to get the largest reductions per dollar spent. For example, if an agency wanted to reduce the P load in the watershed by $20 \%$ per year it would cost $\$ 1,510,000$ if only 'conservation tillage' was implemented compared to $\$ 410,000$ if only the 'wheat to bermuda' practice was implemented. This cost can be further reduced to around $\$ 214,000$ if the practices were implemented in only target areas. By first considering the correct practice and location, a considerable amount of money can be saved while getting the same improvement in water quality.

Typically farmers and ranchers are more willing to implement conservation practices that pay for themselves with increased crop or forage yields and/or decreased inputs, are easy to install and maintain and do not alter their management requirements. Therefore, the out of pocket cost and the impact on the management of their operation to implement a conservation practice must be considered when selecting conservation practices to recommend for cost share programs. However, at the same time the cost per mass of pollutant reduction must be a primary consideration to determine the cost share rates. TBET provided an easy to use and cost effective and efficient tool to provide information to help determine cost share rates for new water quality programs as well as 
providing the potential load reductions for actual conservation practices implemented.

\section{ACKNOWLEDGEMENT}

We would like to thank the Oklahoma Conservation Commission for funding the project and providing the locations and data for the field sites. We would also like to thank Alex Tobergte of Oklahoma State University in helping out with this project and Phil Busteed of the Agricultural Research Service for aiding in the identification of the targeted areas.

\section{REFERENCES}

Allan, J.D., 1995. Stream Ecology: Structure and Function of Running Waters. 1st Edn., Springer, ISBN-10: 0412355302, pp: 400.

Arnold, J.G., R. Srinivasan, R.S. Muttiah and J.R. Williams, 1998. Large area hydrologic model development and assessment part 1: Model development. J. Am. Water Res., Assoc.., 34: 73-89. DOI: $10.1111 /$ j.1752-1688.1998.tb05961.x

Boardman, A.D., V.V. Grimalsky, Y.S. Kivshar, S.V. Koshevaya and M. Lapine et al., 2011. Active and tunable metamaterials. Laser Photonics Rev., 5: 287-307. DOI: 10.1002/lpor.201000012

Bracmort, K.S., M. Arabi, J.R. Frankenberger, B.A. Engel and J.G. Arnold, 2006. Modeling long-term water quality impact of structural BMPs. Trans. ASAE, 49: 367-374.

Canada, C. and J. Zinn, 2005. Environmental Quality Incentives Program (EQIP) status and issues.

Chang, C.L., S.L. Lo and S.M. Huang, 2009. Optimal strategies for best management practice placement in a synthetic watershed. Environ. Monit Assess, 153: 359-364. PMID: 18551374

Chu, T., A. Shirmohammadi, L. Abbott, A. Sadeghi and H. Montas, 2005. Watershed level BMP evaluation with SWAT. Proceedings of the ASAE Annual International Meeting, (AIM' 05), St. Joseph, MI.

Gitau, M.W., T.L. Veith and W.J. Gburek, 2004. Farmlevel optimization of CONSERVATION PRACTICE placement for cost-effective pollution reduction. Trans. ASAE, 47: 1923-1931.

Hossain, I., F.M. Epplin, G.W. Horn and E.G. Krenzer, 2004. Wheat production and management practices used by Oklahoma grain and livestock producers. State University, Stillwater, Okla.

OCC, 2008. Watershed based plan for the central North Canadian Watershed Oklahoma Conservation Commission.
Rao, N.S., Z.M. Easton, E.M. Schneiderman, M.S. Zion and D.R. Lee et al., 2009. Modeling watershed-scale effectiveness of agricultural best management practices to reduce phosphorus loading. J. Environ. Manage., 90 : 1385-1395. DOI: 10.1016/j.jenvman.2008.08.011

Santhi, C., R. Srinivasan, J.G. Arnold and J.R. Williams, 2006. A modeling approach to evaluate the impacts of water quality management plans implemented in a watershed in Texas. Environ. Model Software, 21: 1141-1157. DOI: 10.1016/j.envsoft.2005.05.013

Schwartz, T., 2010. Six ingredients of a good life. IESE.

Secchi, S., P.W. Gassman, M. Jha, L. Kurkalova and H.H. Feng et al., 2007. The cost of cleaner water: Assessing agricultural pollution reduction at the watershed scale. J. Soil Water Cons., 62: 10-21.

Storm, D.E., P.R. Busteed, M.J. White, S. Stoodly and B.J. Berasi, 2007. Middle North Canadian Basintargeting critical source areas and modeling Lake Overholser. 1st Edn., Oklahoma Conservation Commission, 130.

Tuppad, P., N. Kannan, R. Srinivasan, C.G. Rossi and J.G. Arnold, 2010. Simulation of agricultural management alternatives for watershed protection. Water Resour. Manage., 24: 3115-3144. DOI: 10.1007/s11269-010-9598-8

USDA-NRCS, 2007. Soil survey geographic (SSURGO) database. USDA-NRCS, Washington D.C.

USDA-NRCS, 2009. National agricultural statistics service database. USDA-NASS, Washington D.C.

USDA-NRCS, 2011. Field Office Technical Guide (FOTG). USDA-NRCS, Washington D.C.

USEPA, 2007. Clean Water Act Section 319(h) grant funds history. U.S. Environmental Protection Agency.

USGS, 1999. National Elevation Dataset (NED). USGS, Reston, VA.

Vache, K.B., J.M. Eilers and M.V. Santelmann, 2002. Water quality modeling of alternative agricultural scenarios in the U.S. corn belt. J. Am. Water Res. Assoc., 38: 773-787. DOI: 10.1111/j.17521688.2002.tb00996.x

White, M.J., D.E. Storm, P.R. Busteed, M.D. Smolen and H. Zhang et al., 2010. A quantitative phosphorus loss assessment tool for agricultural fields. Environ. Model. Softw., 25: 1121-1129. DOI: 10.1016/j.envsoft.2010.03.017

White, M.W., R.D. Harmel and R.L. Haney, 2012. Development and validation of the Texas Best Management Practice Evaluation Tool (TBET). J. Soil Water Conserv., 67: 525-535. DOI: 10.2489/jswc.67.6.525 